\title{
Strategi komunikasi city branding pemerintah kota Pekalongan dalam mempromosikan world's city of Batik
}

\author{
Hadanilla Ilma Faradies a,1,* \\ ${ }^{a}$ Ilmu Komunikasi UAD Himakom \\ ${ }^{1}$ Hadanillailma@comm.uad.ac.id*; \\ * corresponding author
}

Article history

Received 30-06-2020

Revised 02-07-2020

Accepted 03-07-2020

\section{Keywords}

Strategi Komunikasi

City Branding

Pekalongan

World's City Of Batik

\begin{abstract}
Dalam Penelitian ini bertujuan untuk memaparkan strategi komunikasi city branding pemerintah kota Pekalongan dalam mempromosikan Word's city of Batik. Penelitian ini menggunakan metode penelitian deskriptif kualitstif dengan teknik pengumpulan data yang dilakukan dengan wawancara, observasi, dan studi pustaka. Adapun tujuan penelitian ini peneliti ingin mengetahui strategi city branding yang dilakukan oleh Dinas Pariwisata, Kebudayaan, Kepemudaan dan Olahraga Pemerintah Kota Pekalongan dalam mempromosikan World's City Of Batik. Hasil penelitian ini adalah bahwa strategi komunikasi city branding pemerintah Kota Pekalongan dalam mempromosikan World's City Of Batik melalui 3 tahap diantaranya: perencanaan, pelaksanaan, dan evaluasi. perencanaan dimulai dari penggunaan strategi komunikasi dan penyusunan program oleh pemerintah Kota Pekalongan. Pelaksanaan diantaranya memfokuskan pada mengenalkan Kota Pekalongan sebagai Kota Batik Dunia dalam mendatangkan wisatawan dengan peningkatan program yang mendukung city branding kota pekalongan seperti pengelolaan museum batik, penyelenggaraan festival tahunan, pembentukan kampung wisata batik, pengelolaan pasar grosir batik setono. Pada penelitian ini juga ditemukan bahwa city branding yang telah dilakukan oleh pemerintah Kota Pekalongan secara bertahap dengan memfokuskan dalam peningkatan promosi pariwisata berbasis batik untuk menunjang city branding.
\end{abstract}

This is an open access article under the CC-BY-SA license.

\section{Introduction}

Kota Pekalongan memiliki industri kreatif yang mampu mempromosikan citra kotanya melalui kerajinan batik. City branding mencakup seluruh potensi yang ada, baik wisata, seni dan budaya. Sektor pariwisata di Pekalongan merupakan sektor yang strategis karena dapat berkontribusi terhadap pertumbuhan perekonomian, menciptakan lapangan kerja, perkembangan investasi, peningkatan pendapatan masyarakat seperti kampung wisata batik, pasar grosir batik terbesar di Pekalongan (Riza, Doratli, \& Fasli, 2012). City branding yang baik akan membuat masyarakat cepat ingat akan kota tersebut. Sama seperti halnya Kota Pekalongan, maka yang langsung terlintas adalah kota Batik. Citra ini sudah melekat lama dalam benak masyarakat (Merrilees, Miller, \& Herington, 2009). Kota Pekalongan dipenuhi oleh pengusaha dan pengrajin batik menawarkan keberagaman motif dan desain batik yang merubahnya menjadi sebuah kota dagang dan kota wisata. Kota Pekalongan sebagai kota Batik yang dipenuhi pengusaha dan pengrajin yang menawarkan keberagaman motif dan desain batik atau bahkan menjadi sebuah kota dagang tempat mencari kerja dan menanam investasi. Semua bisa saja dilakukan, tergantung pada potensi yang dimiliki, termasuk culture dan nature Kota Pekalongan itu sendiri. Pekalongan sudah lama dikenal sebagai Kota Batik. 
Dwi Ariputranto, Sekretaris Daerah Kota Pekalongan mengatakan, kehidupan masyarakat kota Pekalongan memang tak bisa lepas dari batik. Hal ini membuat UNESCO memberi perhatian tersendiri pada Pekalongan. Dikatakan Dwi, pada tanggal 1 Desember 2014 lalu, UNESCO menetapkan kota ini sebagai salah satu jaringan kota kreatif. Pekalongan terpilih sebagai jaringan kota kreatif dalam kategori Craft and Folk Arts.

(http://creativecityunesco.pekalongankota.go.id/home/)

Dalam hal ini, Kota Pekalongan mempunyai tantangan tersendiri dalam menjadikan Wolrd's City of Batik sebagai city branding. peneliti tertarik dengan program yang diusung pemerintah Kota Pekalongan dalam menyusun strategi city branding dalam mempromosikan world's city of batik. Namun strategi komunikasi city branding apakah sudah tampak dilakukan oleh pemerintah Kota Pekalongan dalam mempromosikan world's city of batik. Untuk itu, menarik untuk diteliti bagaimana strategi komunikasi pemerintah Kota Pekalongan untuk membangun citra sebagai kota batik, dan apakah pesan dalam program ini telah sampai kepada masyarakat sebagai komunikannya (Jones, 2003).

\section{Theorotocal Framework}

\section{1) Strategi komunikasi}

Berbicara tentang strategi komunikasi ditinjau dari pengertian harfiahnya "merupakan suatu kemampuan manajemen dalam mencapai tujuan". Lasswell mengatakan bahwa cara yang baik untuk menjelaskan komunikasi ialah menjawab pertanyaan sebagai berikut: who says what in which channel to whom with what effect? Jadi, berdasarkan paragidmalasswekk tersebut, komunikasi adalah poses penyampaian pesan oleh komunikator kepada komunikan melalui media yang menimbulkan efek tertentu (Azizah \& Adawia, 2018).

\section{2) City branding}

Pemahaman tentang city branding. Identitas sebuah kota menurut Kampschulte dalam Yananda dan Salamah (Arif, 2012), yang disebut sebagai citra kota, merupakan gambaran dari sebuah kota yang dideskripsikan sebagai hubungan antara ruang nyata dan objektif dengan persepsi yang ditimbulkan dari ruang tersebut. Tujuan City branding Alasan logis melakukan city branding : (1) Memperkenalkan kota/ daerah lebih dalam. (2) Memperbaiki citra. (3) Menarik wisatawan asing dan domestik. (4) Menarik minat investor untuk berinvestasi. (5) Meningkatkan perdagangan (Murphy, 1988).

\section{3) Komunikasi Pemasaran}

Komunikasi pemasaran adalah aktibitas pemasaran yang berusaha menyebarkan informasi, mempengaruhi atau membujuk, dan mengingatkan pasar sasaran atas perusahaan dan produknya agar bersedia menerima, membeli, dan loyal pada produk yang ditawarkan perusahaan yang bersangkutan (Tulasi, 2012).

\section{Method}

Peneliti menerapkan metode studi deskriptif yang bertujuan untuk membuat deskripsi secara sistematis, faktual, dan akurat tentang fakta-fakta dan sifat-sifat populasi atau objek tertentu. Subyek riset ini adalah Dinas Pariwisata, Kebudayaan, Kepemudaan Dan Olahraga Pemerintah Kota Pekalongan. Objek penelitian ini adalah strategi komunikasi city branding yang dilakukan oleh Dinas Pariwisata, Kebudayaan, Kepemudaan Dan Olahraga Pemerintah Kota Pekalongan dalam mempromosikan world's city of batik. Waktu penelitian yang akan peneliti lakukan yaitu selama tiga bulan yaitu pada Juli 2019 sampai dengan September 2019. Data ini merupakan data yang dikumpulkan dengan melakukan depth interview kepada beberapa informan kunci. Data sekunder merupakan data yang diperoleh dari studi kepustakaan atau buku literatur, publikasi nasional dan lain lain. (1) Wawancara mendalam, Wawancara mendalam dengan mencari informasi tentang strategi Komunikasi city branding Dinas Pariwisata, Kebudayaan, Kepemudaan Dan Olahraga Pemerintah Kota Pekalongan. (2) Observasi, ada beberapa bentuk obervasi yang dapat digunakan 
dalam penelitian kualitatif. (3) Dokumentasi, Kegiatan mengumpulkan data, baik dari dokumen Pengelola, buku-buku maupun literatur yang relevan (Sugiyono, 2015).

Setelah dilakukan penelitian dan diperoleh data, maka data akan dianalisis sehingga dapat menemukan deskripsi berkenaan tentang strategi komunikasi city branding Kota Pekalongan dalam mempromosikan world's city of batik. Untuk menjaga keabsahan data dalam penelitian ini, peneliti menggunakan teknik triagulasi data.

\section{Results and Discussion}

Peneliti menyajikan data berdasarkan tiga sub penyajian. Pertama pemaparan data peneitian pada perencanaan, selanjutnya menyajikan data pelaksanaan yang dilakukan oleh objek penelitian, serta data evaluasi. Perencanaan strategi city branding pemerintah kota pekalongan dalam mempromosikan World's City Of Batik. Pemerintah Kota Pekalongan menggunakan strategi komunikasi untuk melakukan city branding. Pemerintah Kota Pekalongan ingin membentuk citra dalam mempromosikan World's City Of Batik yaitu menjadi kota kreatif dunia dengan kategori craft and folk art. Pemerintah Kota Pekalongan bersinergi dengan akademisi, pengusaha, komunitas, pemerintah dan juga media. Upaya yang dilakukan oleh Pemerintah Kota Pekalongan tersebut menunjukan bahwa strategi komunikasi merupakan cara efektif dan efisien. Strategi komunikasi baik secara langsung (tatap muka) maupun tidak langsung (melalui media) sudah berjalan dan akan terus dilakukan demi terciptanya tujuan bersama untuk memperkenalkan batik sebagai budaya di Pekalongan sebagaimana slogan yang ada The World's city of batik. Selanjutnya, Pemerintah Kota Pekalongan menggunakan strategi komunikasi dalam melakukan city branding bertujuan untuk mempromosikan Kota Pekalongan, membangun serta mempertahankan citra Kota Pekalongan sebagai kota batik dunia.

Langkah-langkah pemerintah Kota Pekalongan untuk menciptakan ekonomi kreatif tentunya akan memberikan dampak bagi masyarakat dan mendorong terciptanya kesadaran untuk mempertahankan budaya yang dimiliki yang berpotensi menguntungkan dari segi pendapatan melalui budaya dan wisata unggul. Strategi yang diambil juga tetap memperhatikan tentang proses produksi yang kreatif dan terjaga kualitasnya. Selanjutnya, kegiatan promosi dan distribusi yang menarik dan berbeda sehingga menarik minat wisatawan terhadap kekhasan Kota Pekalongan sebagai Worlds City of Batik. Pelaksanaan Strategi City Branding Pemerintah Kota Pkelaongan dalam Mempromosikan World's City Of Batik. Sejak kepemimpinan walikota Dr. H. M Basyir Ahmad keberadaan batik diangkat secara maksimal sehingga pamornya mencuat dalam beberapa tahun terakhir ini sampai tercetus membentuk branding Pekalongan World's City Of Batik. . Setelah adanya slogan World's City Of Batik mempermudah Kota Pekalongan memperkenalkan, dan mempromosikan dengan cakupan yang lebih luas.

Pemerintah Kota Pekalongan dengan strategi promosi yang dilakukan tentunya melihat dari berbagai aspek, baik itu lingkungan, sosial, budaya dan seni yang ada di Pekalongan. Sehingga diharapkan anggaran-anggaran yang dirancang nantinya akan lebih efisien dan tepat sasaran diberbagai kegiatan dalam pencapaian tujuan Kota Pekalongan sebagai World's City Of Batik. Program impelementasi promosi World's City Of Batik merupakan salah satu program pelaksanaan strategi city branding Kota Pekalongan diantaranya Pengelolaan Meseum Batik, Penyelenggaraan Festival Tahunan, Pembentukan Kampung wisata batik dan Pengelolaan Pasar grosir batik. Program ini diusung diantaranya untuk memperkuat strategi city branding Kota Pekalongan sebagai Kota Batik Dunia, salah satu upaya pemerintah yang ditujukan masyarakat Pekalongan dan wisatawan pada umumnya.

Evaluasi strategi city branding pemerintah kota pkelaongan dalam mempromosikan World's City Of Batik. Strategi komunikasi merupakan bagian yang sangat penting dalam upaya pencapaian tujuan pemerintah Kota Pekalongan mempromosikan World's City of Batik. Dalam tahapan perencanaan memerlukan strategi yang matang, pelaksaan kegiatan promosi juga harus dibarengi kerjasama diberbagai pihak yang ada sehingga Pekalongan mampu menjadi kota kreatif dunia sepenuhnya. Tahapan yang dilalui memerlukan adanya evaluasi yang terarah dan berdampak positif bagi masa yang akan datang sebagai bahan acuan dan refleksi baik bagi pemerintah dan masyarakat pada umumnya. Pemerintah Kota Pekalongan secara berkala melakukan evaluasi terhadap hasil

Hadanilla Ilma Faradies (Strategi komunikasi city branding pemerintah kota Pekalongan dalam mempromosikan world's city of Batik) 
pelaksanaan strategi komunikasi dalam mempromosikan City branding demi mewujudkan kota kreatif dunia yang seutuhnya sesuai dengan slogan World's city of batik. Setiap kegiatan yang dilakukan dan sudah dievaluasi tentunya harus ada perbaikan dimasa akan datang.

1) Efektivitas Proses Perencanaan Strategi City Branding Pemerintah Kota Pekalongan dalam Mempromosikan World's City Of Batik

Pemerintah Kota Pekalongan membuat perencanaan dan manajemen untuk mencapai suatu tujuannya yakni city branding. Dalam melakukan city branding pemerintah Pekalongan menggunakan strategi komunikasi baik secara langsung (tatap muka) maupun tidak langsung (media masa). Hal tersebut bertujuan untuk lebih memepromosikan World's City Of Batik baik ke masyarakat lokal maupun wisatawan. Strategi yang dilakukan oleh Pemerintah Kota Pekalongan adalah membangun kesadaran masyarakat akan pentingnya menjaga dan melestarikan warisan budaya yang ada di Pekalongan. Menurut Prof. Drs. Onong Uchjana Effendy MA (2013:8), menyebutkan tujuan komunikasi berikutnya adalah:

a) Mengubah sikap (to change the attitude)

Tujuan pemerintah Pekalongan dalam membuat strategi city branding iniadalah untuk mengubah sikap stakeholder mengenai brand Kota Pekalongan sebagai Kota batik dan juga sebagai kota kreatif dunia dalam kategori craft and folk art.

b) Mengubah opini/pendapat/pandangan (to change the opinion)

Pemerintah Kota Pekalongan merancang strategi city branding untuk dapat mengubah pendapat stakeholder atas citra Kota Pekalongan agar semakin positif.

c) Mengubah perilaku (to change the behavior)

Penerapan Slogan sebagai strategi komunikasi city branding Kota Pekalongan dalam mempromosikan World's City Of Batik bertujuan untuk mengubah perilaku masyarakat untuk semakin kreatif dan inovatif.

d) Mengubah masyarakat (to change the society)

Tujuan utama dalam merancang strategi komunikasi city branding Kota Pekalongan dalam mempromosikan World's City Of Batik adalah mengubah masyarakat yang belum tahu menjadi tahu. Setelah mengetahuinya diharapkan stakeholder dapat memahami dan mengaplikasikan kebijakan-kebijakan yang telah diusung oleh pemerintah.

2) Efektivitas Proses Pelaksanaan Strategi City Branding Pemerintah Kota Pekalongan dalam Mempromosikan World's City Of Batik

Upaya-upaya yang dilakukan pemerintah Kota Pekalongan dalam melakukan Proses komunikasi sesuai dengan teori menurut Onong Uchjana Effendy (2011 : 11) yaitu proses komunikasi secara primer dan secara sekunder, Kegiatan promosi dilakukan oleh pemerintah Pekalongan untuk mengenalkan branding World's City Of Batik kepada masyarakat dengan mempengaruhi agar semakin banyak wisatawan yang datang ke Kota Pekalongan. Untuk lebih mengefektifkan promosi yang dilakaukan, Kota Pekalongan mengkombinasikan beberapa unsur bauran promosi. Kotler \& Amstrong (2008:116) menjelaskan bahwa bauran promosi (promotion mix) merupakan paduan spesifik iklan, promosi penjalan, hubungan masyarakat, penjual personal, dan sarana pemasaran langsung yang digunakan perusahaan untuk mengkomunikasikan nilai pelanggan secara persuasif dan membangun gabugan pelanggan. Program impelementasi promosi World's City Of Batik merupakan salah satu program pelaksanaan strategi city branding Kota Pekalongan diantaranya Pengelolaan Meseum Batik, Penyelenggaraan Festival Tahunan, Pembentukan Kampung wisata batik dan Pengelolaan Pasar grosir batik. Program ini diusung diantaranya untuk memperkuat strategi city branding Kota Pekalongan sebagai Kota Batik Dunia, salah satu upaya pemerintah yang ditujukan masyarakat Pekalongan dan wisatawan pada umumnya. Tahap pelaksanakaan dalam strategi komunikasi city branding kota pekalongan dalam mempromosikan World's City Of Batik menjadi konsentrasi dinas pariwisata kebudayaan kepemudaan dan olahraga. Proses evaluasi ini dilakukan dinparbudpora secara berkala melakukan pengawasan dan peninjauan terhadap hasil yang dicapai dalam kurun waktu yang telah ditentukan. Hal ini dimaksudkan agar alam strategi promosi baik perencanaan dan pelaksanaan diwaktu mendatang dapat lebih baik dari sebelumnya. Proses evaluasi pada tahap pelaksanan ini sama halnya dengan tahap perencanaan. Evaluasi dilakukan 
setiap triwulan dan indikator utamanya mengevaluasi berapa kunjungan wisatawan, berapa pendapatan dari pariwisata, berapa pajak dari pariwisata.

3) Evaluasi Pelaksanaan Strategi City branding Pemerintah Kota Pekalongan Dalam Mempromosikan World's City Of Batik.

City branding yang dimiliki Pekalongan berfokus pada Batik yang menjadi ciri khasnya. Batik menjadi potensi besar yang kemudian menginspirasi dan menjadi dasar adanya branding kota Pekalongan World's City Of Batik. Program implementasi strategi komunikasi city branding dalam mempromosikan World's City Of Batik juga terdapat evaluasi dari masing-masing program. Pemerintah melakukan evaluasi dari target kunjungan wisatawan, efektifitas jalur-jalur promosi, selain itu juga evaluasi dari desai-desain media promosi dan bentuk promosi. Program implementasi strategi komunikasi city branding dalam mempromosikan World's City Of Batik juga terdapat evaluasi dari masing-masing program, antara lain. (1) Pengelolaan Museum Batik, evaluasi dilakukan tiap bulan dengan mengevaluasi kinerja pegawai museum dan juga target kunjungan wisatawan. (2) Penyelenggaraan festival tahunan, Kota Pekalongan terdapat banyak festival yang diselenggarakan setiap tahunya. Masing-masing festival melakukan evaluasi setelah acara tersebut selesai diselenggarakan. Evaluasi ini tujuannya untuk bahan acuan kedepannya agar lebih baik dari tahun ke tahun. (3) Pembentukan kampung wisata batik, dikenal sebagai salah satu kota batik dunia, kota pekalongan memiliki beberapa kampung wisata batik yaitu kampung wisata batik kauman, kampung wisata batik pesindon dan kampung wisata batik jlamprang. Ketiga kampung wisata tersebut melakukan evaluasi tiap enam bulan sekali. Proses evaluasi dari mulai target kunjungan wisatawan, Pendapatan serta masalah-masalah yang ada dilapangan. (4) Pengelolaan pasar grosir batik, pemerintah kota pekalongan dalam mengevaluasi pasar grosir batik dengan mendata penjual atau pengusaha batik yang memiliki ruko di pasar grosir batik setono setiap tahunnya serta mendata berapa persen barang atau batik yang di ekspor dari pasar grosir setono setiap tahunnya.

\section{Conclusion}

Berdasarkan hasil penelitian yang dilakukan di Dinas Pariwisata, Kebudayaan, Kepemudaan dan Olahraga yakni Strategi komunikasi City Branding pemerintah Kota Pekalongan dalam mempromosikan World's City of Batik, dapat ditarik kesimpulan bahwa:

1) Perencanaan Strategi Komunikasi City branding Pemerintah Kota Pekalongan dalam Mempromosikan World's City Of Batik

Perencanaan dimulai dari penerapan visi dan misi, pencapaian tujuan yang diusung oleh kepala daerah dan dilaksanakan oleh Badan Perencanaan dan Pembangunan Daerah Kota Pekalongan Kota Pekalongan. Selanjutnya dibantu pula oleh Dinas Pariwisata Kebudayaan kepemudaan dan Olahraga Kota Pekalongan. Kemudian merancang program-program yang berkaitan dengan slogan World's City of Batik sebagai upaya melestarikan batik sebagai warisan budaya Kota Pekalongan. Langkahlangkah pemerintah Kota Pekalongan untuk menciptakan ekonomi kreatif tentunya akan memberikan dampak bagi masyarakat dan mendorong terciptanya kesadaran untuk mempertahankan budaya yang dimiliki yang berpotensi menguntungkan dari segi pendapatan melalui budaya dan wisata unggul. Adanya berbagai program, kegiatan dan festival atau event yang ada di Kota Pekalongan, adanya pengelolaan tempat-tempat wisata yang menjadikan batik sebagai ciri khasnya seperti Museum Batik, Pasar grosir Batik, Kampung wisata batik yang wajib dikunjungi ketika berada di Kota Pekalongan. Selain itu, upaya yang dilakukan Pemerintah Kota Pekalongan juga tak lain adalah dengan menggandeng berbagai pihak seperti pengusaha dan pengrajin batik, generasi muda yang aktif dalam bermedia massa serta berbagai pihak untuk bersama-sama menjadikan batik tetap eksis dan berkembang secara kreatif serta inovatif sesuai dengan perkembangan zaman.

2) Pelaksanaan Strategi Komunikasi City Branding Pemerintah Kota Pekalongan dalam Mempromosikan World's City Of Batik

Pada tahap pelaksanaan, strategi komunikasi city branding Pemerintah Kota Pekalongan dalam hal ini melaksanakan secara langsung maupun tidak langsung. Program yang sejalan diantaranya adalah penegelolaan museum batik Kota Pekalongan, Penyelenggaraan festival tahunan, Pembentukan kampung wisata batik, Pengelolaan pasar grosir batik dan berbagai upaya dalam melestarikan batik sebagai city branding Kota Pekalongan baik melalui pengenalan secara langsung maupun melalui media-media.

Hadanilla Ilma Faradies (Strategi komunikasi city branding pemerintah kota Pekalongan dalam mempromosikan world's city of Batik) 
3) Evaluasi Pelaksanaan Strategi Komunikasi City Branding Pemerintah Kota Pekalongan dalam Mempromosikan World's City Of Batik

Tahap terakhir yang dilakukan adalah dengan melakukan evaluasi secara berkala, dimana Pemerintah Kota Pekalongan secara rutin melakukan berbagai ketiatan evaluasi baik sebelum mulai dari tahap perencanaan sampai dengan pelaksanaan. Evaluasi dilakukan agar mengetahui seberapa besar tujuan yang tercapai diberbagai sektor dalam upaya strategi komunikasi city branding di Kota Pekalongan dalam mempromosikan World's city of Batik. Pada Penelitian ini juga ditemukan bahwa city branding yang ada di Kota Pekalongan telah dilaksanakan dengan baik, karena pemerintah Kota Pekalongan memfokuskan dalam peningkatan pariwisata untuk menunjang strategi komunikasi dalam mempromosikan World's city of Batik baik untuk masyarakat lokal maupun wisatawan.

\section{References}

Arif, D. sulisworo ; T. wahyuningsih \& D. baehaqi. (2012). Identitas Nasional. Hibah Materipembelajaran Non Konvesional. https://doi.org/10.1109/ICACC.2012.2

Azizah, A., \& Adawia, P. R. (2018). strategi pemasaran. Cakrawala - Jurnal Humaniora. https://doi.org/10.31294/JC.V18I2.4117

Jones, J. P. (2003). Advertising and Promotion. In Encyclopedia of International Media and Communications. https://doi.org/10.1016/B0-12-387670-2/00002-9

Merrilees, B., Miller, D., \& Herington, C. (2009). Antecedents of residents' city brand attitudes. Journal of Business Research. https://doi.org/10.1016/j.jbusres.2008.05.011

Murphy, J. (1988). Branding. Marketing Intelligence \& Planning. https://doi.org/10.1108/eb045775

Riza, M., Doratli, N., \& Fasli, M. (2012). City Branding and Identity. Procedia - Social and Behavioral Sciences. https://doi.org/10.1016/j.sbspro.2012.02.091

Sugiyono. (2015). Metode Penelitian. Metode Penelitian.

Tulasi, D. (2012). Komunikasi Pemasaran. Humaniora. 